
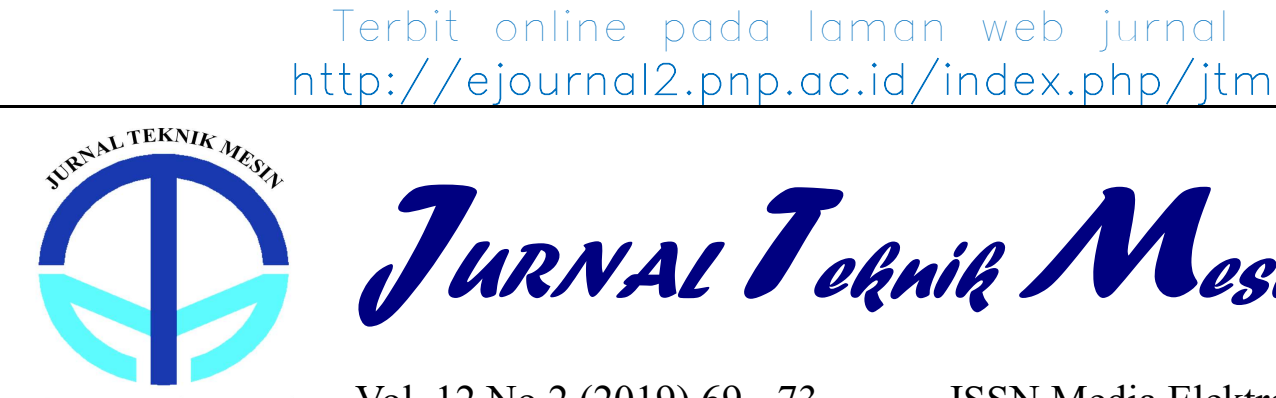

JuRnal Tolmuli Mesin

POLITEKNIK NEGERI PADANG

Vol. 12 No.2 (2019) 69 - 73

ISSN Media Elektronik: 2655-5670

\title{
PERBAIKAN KUALITAS MATA PISAU MESIN IRAT BAMBU DENGAN PROSES HEAT TREATMENT MELALUI BAJA FASA GANDA
}

\author{
Togik Hidayat ${ }^{1}$, Teguh Raharja ${ }^{2}$ \\ ${ }^{1,2}$ Program Studi Teknik Mesin, Fakultas Sains dan Teknologi, Universitas Nahdlatul Ulama Sunan Giri \\ ${ }^{1}$ togikhidayat@gmail.com ${ }^{2}$,suteguhraharja1986@gmail.com
}

\begin{abstract}
Blades bamboo irat machine play an important role in quality of bamboo products creative industry in Kebonagung Village, Padangan District, Bojonegoro Regency. Cutting tools must have the characteristics of producing good cutting quality [9]. How to improve the mechanical characteristic of the blade is to do heat treatment, surface treatment, coating and others [5]. This research was conducted with the aim to improve quality of blade bamboo irat machine by knowing changes in mechanical characteristic through changes in microstructure, optimal hardness value, and maximum tensile strength. The study was conducted by experimental method using laboratory scale analysis. Heat treatment process of the blade bamboo irat is carried out at $725{ }^{\circ} \mathrm{C}$ with a holding time of 10 minutes, 20 minutes, 30 minutes, tempering at $600{ }^{\circ} \mathrm{C}$ for 20 minutes. Results of microstructure test blade with a holding time of 30 minutes have a finer and evenly distributed metal grain size resulting. The highest hardness value is $59.13 \mathrm{HRC}$ on the blade with holding time of 30 minutes. The highest average modulus of elasticity is in the specimen with holding time of 20 minutes which is $6.87 \mathrm{~N} / \mathrm{mm}^{2}$.
\end{abstract}

Keywords: Blade Irat machine, Dual Phase Steel, Heat Treatment.

\begin{abstract}
Abstrak
Mata pisau mesin irat bambu berperan penting dalam menentukan kualitas produk industri kreatif bambu di desa Kebonagung Kecamatan Padangan Kabupaten Bojonegoro. Alat pemotong harus memiliki karakteristik menghasilkan kualitas pemotongan baik [9] . Kualitas pisau mesin irat bambu dapat dilihat dari hasil potongan dan life time. Faktor yang mengurangi kualitas dan life time mata pisau adalah gesekan dan panas. Cara meningkatkan kualitas dan life time dapat dilakukan dengan memperbaiki sifat mekanisnya. Perbaikan sifat mekanis dapat dilakukan melalui heat treatment, surface treatment, coating dan lain-lain [5]. Penelitian ini dilakukan dengan tujuan untuk meningkatkan kualitas mata pisau mesin irat bambu dengan mengetahui perubahan sifat mekanis melalui perubahan struktur mikro, nilai kekerasan optimal, dan kekuatan tarik maksimal. Penelitian dilakukan dengan metode eksperimen menggunakan analisis skala laboratorium. Proses heat treatment mata pisau irat bambu dilakukan pada temperatur $725^{\circ} \mathrm{C}$ dengan holding time 10 menit, 20 menit, 30 menit, proses tempering pada temperatur $600^{\circ} \mathrm{C}$ selama 20 menit. Hasil uji struktur mikro mata pisau dengan holding time 30 menit memiliki ukuran butir logam yang lebih halus dan merata. Nilai kekerasan tertinggi adalah 59,13 HRC pada mata pisau dengan holding time 30 menit. Nilai rata - rata modulus elastisitas tertinggi adalah pada specimen dengan holding time 20 menit yaitu $6,87 \mathrm{~N} / \mathrm{mm}^{2}$.
\end{abstract}

Kata kunci: Baja Fasa Ganda, Heat Treatment, Pisau mesin irat.

\section{Pendahuluan}

Perbaikan struktur mikro dan peningkatan sifat mekanis suatu bahan merupakan solusi tepat guna menghasilkan produk baja yang mampu mencegah terjadinya kerusakan dari peralatan/ komponen mesin lainya akibat perlakuan berat seperti yang terjadi pada mata pisau baja mesin irat bambu yang banyak digunakan pada operasional produksi Industri Keratif
Menengah (IKM) di Desa Kebonagung Kecamatan Padangan Kabupaten Bojonegoro. Kualitas pisau sangat mempengaruhi hasil dari irat bambu yang dijalankan oleh pelaku IKM bambu di Desa Kebunagung. Selain kualitas hasil dari irat bambu, life time mata pisau juga menjadi kendala dalam proses produksi bambu karena sparepart pisau yang sulit dicari dan harganya yang relatif mahal. 
Pisau mesin irat bambu menggunakan material baja dalam pengaplikasiannya. Baja adalah salah satu logam ferro yang banyak digunakan dalam dunia teknik dan industri. Kandungan utama unsur pada baja terdiri dari kandungan besi (Fe) pada baja sekitar 97\% dan karbon (C) sekitar $0,2 \%$ hingga 2,1\% sesuai grade-nya. Selain unsur besi $(\mathrm{Fe})$ dan karbon $(\mathrm{C})$, baja mengandung unsur lain seperti mangan $(\mathrm{Mn})$ dengan kadar maksimal 1,65\%, silikon (Si) dengan kadar maksimal $0,6 \%$, tembaga $(\mathrm{Cu})$ dengan kadar maksimal $0,6 \%$, sulfur $(\mathrm{S})$, fosfor $(\mathrm{P})$ dan unsur lainnya dengan jumlah yang dibatasi dan berbedabeda [11].

Struktur logam mata pisau mesin irat bambu akan mengalami pengaruh gaya luar berupa tegangan gesek karena kerja mekanis sehingga menimbulkan panas dan menyebabkan terjadinya deformasi. Proses yang dapat dilakukan untuk menjaga logam supaya lebih tahan terhadap gesekan atau tekanan adalah dengan proses perlakuan panas (heat-treatment). Proses heat treatment ini meliputi proses pemanasan baja pada suhu tertentu, kemudian proses panas yang dipertahankan pada waktu tertentu dan diikuti proses pendinginan dengan menggunakan media tertentu pula. Proses heat treament terhadap baja pada umumnya akan melibatkan transformasi atau dekomposisi fasa austenite baja. Struktur dan bentuk dari baja hasil transformasi atau dekomposisi austenit inilah yang mempengaruhi sifat fisis dan mekanis baja melalui proses heat treatment. Melalui proses heat treatment ini diharapkan dpat meningkatkan kualitas dan memperpanjang life time dari mata pisau mesin irat bambu

Heat treatment mempunyai tujuan untuk meningkatkan keuletan, menghilangkan tegangan internal, menghaluskan butir kristal, meningkatkan tegangan tarik logam dan lainnya. Tujuan ini akan tercapai seperti apa yang diinginkan jika memperhatikan faktor-faktor yang mempengaruhinya seperti waktu penahanan, suhu pemanasan dan media pendingin yang digunakan. Proses heat treatment yag sering diterapkan pada pengolahan baja adalah proses pengerasan (hardening) yaitu proses perlakuan panas pada baja sampai pada atau diatas suhu daerah kritis diikuti dengan proses pendinginan yang cepat (quenching). Proses pengerasan/ hardening pada baja dapat menimbulkan tegangan dalam (internal stress) dan rapuh (britles) pada baja, sehingga baja perlu dilakukan proses lanjut yaitu proses tempering, dengan proses tempering sifat mekanis baja berupa kegetasan dan kekerasan dapat diturunkan sampai memenuhi syarat penggunaan, kekuatan tarik turun sedangkan keuletan dan ketangguhan meningkat [3]. Proses tempering bertujuan untuk mendapatkan baja yang lebih tangguh (tough) dan liat (ductile) tanpa banyak mengurangi kekuatan (strength) [1].

Penelitian dilakukan dengan tujuan untuk meningkatkan kualitas mata pisau mesin irat bambu melalui proses heat treatment dengan mengetahui perubahan struktur mikro yang telah dibentuk, mengetahui nilai kekerasan yang paling optimal dari beberapa pengujian pada proses heat treatment dengan penahanan waktu yang paling optimal, dan mengetahui kekuatan tarik maksimal dengan penahanan waktu yang paling optimal.

\section{Metode Penelitian}

Metode penelitian yang digunakan dalam mengerjakan penelitaian sesuai dengan tujuan yang ingin dicapai adalah melalui metode eksperimen dengan menggunakan analisis skala laboratorium, Proses heat treatment pada mata pisau mesin irat bambu dilakukan pada temperature $725^{\circ} \mathrm{C}$ dengan holding time 10 menit, 20 menit, 30 menit, proses tempering pada temperatur $600^{\circ} \mathrm{C}$ selama 20 menit. Dimanan setiap proses dalam penelitian ini memiliki tujuan tersendiri sedangkan penentuan variasi waktu penahanan dilakukan untuk pemilihan proses berdasarkan hasil yang terbaik yang diperoleh berdasarkan atas hasil uji sifat mekanis. Secara umum alur dalam penelitian digambarkan dalam Gambar 1.

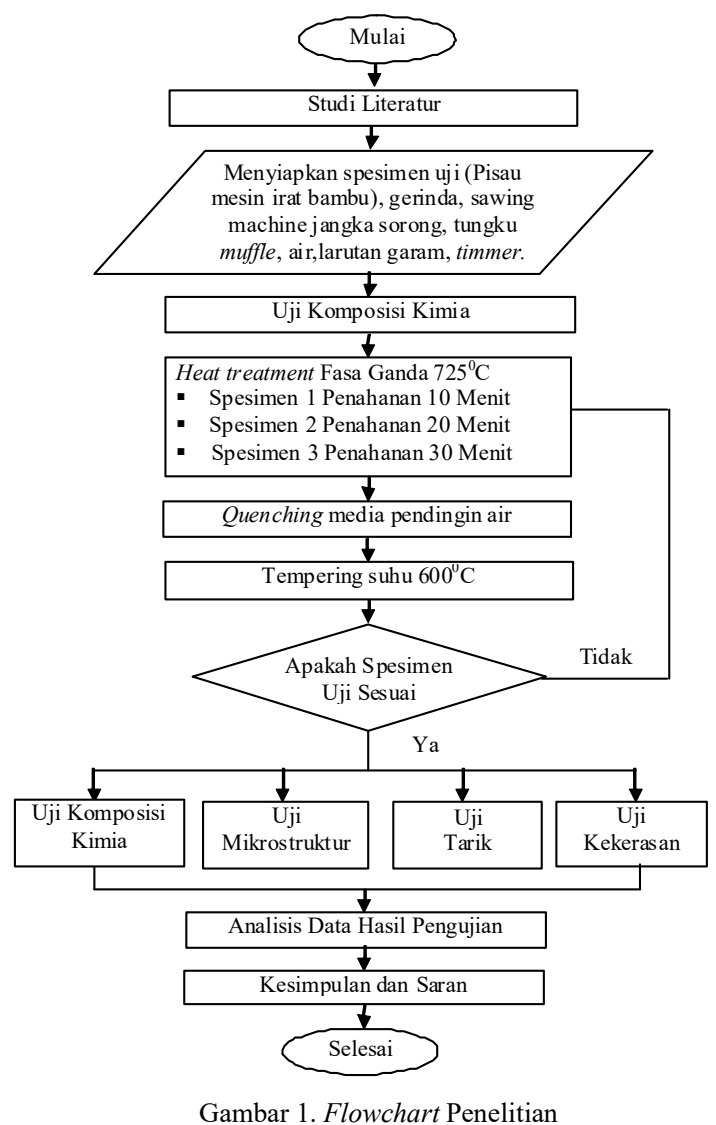

Studi literatur dalam penelitian ini meliputi kegiatan awal penelitian yang meliputi kegiatan pengumpulan data tentang pisau mesin irat bambu, proses heat treatment, proses quenching, proses tempering, pengujian sifat mekanis yang terdiri dari uji komposisi kimia unsur, uji mikrostruktur, uji kekerasan bahan, uji tarik, dan studi literatur tentang metode penelitian yang relevan untuk digunakan sesuai dengan tujuan penelitian yang ingin dicapai berdasarkan dari buku, 
artikel, penelitian sebelumnnya yang sesuai. Berdasarkan kegiatan studi literatur dapat ditentukan peralatan, perlengkapan dan bahan yang dibutuhkan untuk mengerjan penelitian.

Kegiatan mempersiapkan peralatan, perlengkapan dan bahan dalam penelitian yang meliputi persiapan mata pisau mesin irat bambu, gerinda, automatic sawing machine, jangka sorong, tungku muffle, media air, media larutan garam, timmer dan beberapa perlengkapan penunjang penelitian lainnya.

Identifikasi komposisi kimia, merupakan kegiatan awal untuk menentukan komposisi unsur dalam mata pisau mesin irat bambu dan menentukan sifat mekanis mata pisau irat bambu sebelum dilakukan proses heat treatment melalui beberapa variasi holding time sehingga terbentuk fasa ganda yang dapat digunakan sebagai acuan/ skala pembanding dalam penelitian untuk menyimpulkan hasil penelitian.

Heat treatment pada mata pisau mesin irat bambu uji dilakukan heat treatment pada temperatur pemanasan $725^{\circ} \mathrm{C}$ dengan variasi waktu penahan 10 menit, 20 menit, dan 30 menit. Proses ini bertujuan untuk membentuk fasa ganda dalam mata pisau mesin irat bambu dan untuk memperbaiki sifat mekanis yang meliputi keuletan, menghilangkan tegangan internal, menghaluskan butir kristal, meningkatkan tegangan tarik logam.

Proses Quencing dilakukan dengan cara memanaskan baja sampai suhu austenit dan dipertahankan dalam waktu tertentu pada suhu fasa austenit, kemudian diikuti pendinginan secara cepat dalam media pendingin air. Proses ini dilakukan dengan tujuan untuk hardening. Ukuran hardening pada baja dengan hasil yang baik adalah bila mendapatkan harga kekerasan, kekuatan, dan toughness yang besar dengan nilai residual stress, distorsi, dan cracking yang minimal. Baja yang mengalami proses quenching memiliki kekerasan yang tinggi serta dapat mencapai kekerasan maksimum tetapi rapuh, sehingga perlu dilakukan tempering untuk mengurangi sifat rapuh karena quenching [6].

Proses Tempering dilakukan dengan tujuan untuk mengurangi tegangan sisa, meningkatkan ketangguhan dan keuletan pada mata pisau mesin irat bambu setelah dilakukan quenching yang telah mengalami pengerasan (terbentuknya fasa martensite). Suhu pada proses pemanasan dilakukan pada saat suhu dapur (furnace) telah mencapai suhu panas yang diinginkan untuk memperoleh bentuk kristal yang baik pada proses transformasi. Waktu pemanasan suhu untuk proses tempering dilakukan dengan tujuan supaya struktur mikro yang dicapai setelah proses menjadi lebih homogen [7]. Heat treatment pada proses tempering dilakukan dengan cara memanaskan material kembali pada temperatur antara $500-700^{\circ} \mathrm{C}$ atau di bawah temperatur kritis kemudian membiarkannya atau menahan suhu tersebut beberapa saat, dan didinginkan dengan proses pendinginan lambat yaitu didinginkan pada media udara terbuka [10].

Pengujian mikrostruktur dilakukan untuk mengetahui struktur mikro dan untuk mengetahi sifat mekanis yang terbentuk pada mata pisau mesin irat bambu yang terbentuk setelah mengalami proses heat treatment serta mengetahui pengaruh heat treatment terhadap perubahan struktur mikro dan perubahan sifat logam serta membandingkannya dengan sifat mekanis yang diinginkannya.

Pengujian tarik ini dilakukan dilakukan untuk mengetahui sifat mekanis berupa ketangguhan terhadap tarikan mata pisau mesin irat bambu setelah mengalami proses heat treatment dimana sifat ketangguhan mata pisau mesin irat bambu dilihat berdasarkan nilai tegangan tarik $(\sigma)$, dan regangan $(\varepsilon)$, dan ketangguhan (U) menggunakan bantuan tensile tester. Pengujian tarik mengacu pada hasil pengujian suatu material dengan cara menarik material hingga titik dimana material akan mengalami tegangan dan regangan maksimum sehingga material patah atau putus, tujuannya adalah mengetahui kemampuan ketahanan dalam tarikan pada suatu tingkatan daya tertentu [2].

Uji kekerasan material dilakukan untuk mengetahui angka kekerasan suatu bahan, mengetahui pengaruh heat treatment terhadap nilai kekerasan atau kekuatan suatu bahan. Pengujian kekerasan dalam penelitian ini dilakukan dengan menggunakan bantuan alat uji kekerasan Rockwell Hardness Test.

Analisis data hasil pengujian mata pisau mesin irat bambu yang telah dilakukan heat treatment dengan membandingkan sesuai dengan skala laboratorium yang diperoleh dari pengujian mata pisau mesin irat bambu sebelum dilakukan proses heat treatment dan kajian pustaka untuk menentukan sifat mekanis bahan yang terbentuk.

Kesimpulan diambil berdasarkan dari hasil penelitian yang disesuaikan analisis dari perbaikan kualitas pisau irat bambu dengan proses heat treatment.

\section{Hasil dan Pembahasan}

\subsection{Hasil Uji Komposisi Bahan}

Pengujian komposisi kimia mata pisau mesin irat bambu menggunakan mesin uji komposisi kimia logam spektrometri pada masing - masing spesimen dengan variasi holding time 10 menit, 20 menit, 30 menit. Hasil pengujian komposisi kimia kemudian dibandingkan dengan standart SAE 1080. Hasil Uji komposisi kimia ditunjukan dalam Tabel 1. 
Tabel 1. Hasil Uji Komposisi Kimia

\begin{tabular}{llllll}
\hline Komposisi & $\mathrm{C}$ & $\mathrm{Si}$ & $\mathrm{Mn}$ & $\mathrm{P}$ & $\mathrm{S}$ \\
\hline 10 menit & 0.786 & 0.311 & 0.834 & 0.0264 & 0.0165 \\
20 menit & 0.779 & 0.323 & 0.828 & 0.0270 & 0.0156 \\
30 menit & 0.768 & 0.333 & 0.830 & 0.0274 & 0.0155 \\
SAE 1080 & $0.76-0.87$ & $0.08-0.5$ & $0.6-0.9$ & $\leq 0.03$ & $\leq 0.05$ \\
\hline
\end{tabular}

Berdasarkan hasil pengujian terhadap komposisi kima yang telah dilakukan dan ditunjukan pada Tabel 1 . dapat diketahui dan disimpulkan bahwa dengan membandingkan pada standard SAE 1080 dapat diketahui komposisi unsur yang membentuk pada mata pisau mesin irat bambu setelah diberikan perlakuan proses heat treatment dengan variasi pada holding time masing-masing 10 menit, 20 menit, 30 menit menunjukan masing-masing unsur yang mebentuk pisau mesin irat bambu adalah $\mathrm{C}, \mathrm{Si}, \mathrm{Mn}, \mathrm{P}$ $\mathrm{S}$ yang terbentuk secara keseluruhan sudah memenuhi standart SAE 1080.

\subsection{Hasil Uji Mikrostruktur}

Pengujian mikrostruktur dalam penelitian ini dilakukan menggunakan bantuan alat Micro Hardenes Tester melalui pembesaran gambar yang diperoleh berdasarkan perkalian antara penggunaan ukuran lensa obyektif dan lensa okuler. Dalam penelitian ini menggunakan lensa obyektif ukuran $10 x$ dan lensa okuler ukuran $10 x$ sehingga perbesaran bisa mencapai $100 x$. Pada jarak 10 setrip pada foto/gambar untuk perbesaran $100 x$ adalah $100 \mu \mathrm{m}$. Pengujian struktur mikro dilakukan untuk memperoleh gambaran permukaan mata pisau mesin irat bambu untuk melihat cacat seperti retak atau cacat lainya, yang dapat diamati melalui teknik metalografi serta mengetahui persentase fasa baja yang terbentuk dalam mata pisau mesin irat bambu. Bagian yang diuji struktur mikro adalah pada titik mata pisau mesin irat bambu dengan waktu penahanan 10 menit, waktu penahanan 20 menit, waktu penahanan 30 menit. Adapun hasil pengujian mikro struktur mata pisau mesin irat bambu ditunjukan dalam Tabel 2.

\begin{tabular}{|c|c|c|}
\hline \multirow[t]{2}{*}{ Variasi } & \multicolumn{2}{|c|}{ Hasil Uji } \\
\hline & Permukaan Logam & $\%$ Fasa \\
\hline $\begin{array}{l}\text { Holding } \\
\text { Time } 10 \\
\text { menit }\end{array}$ & & $\begin{array}{l}\text { Ferit }: 90.37 \% \\
\text { Martensite }: 9.63 \%\end{array}$ \\
\hline $\begin{array}{l}\text { Holding } \\
\text { Time } 20 \\
\text { menit }\end{array}$ & & $\begin{array}{l}\text { Ferit }: 85.14 \% \\
\text { Martensite }: 14.86 \%\end{array}$ \\
\hline $\begin{array}{l}\text { Holding } \\
\text { Time } 30 \\
\text { menit }\end{array}$ & & $\begin{array}{l}\text { Ferit } \quad: 83.02 \% \\
\text { Martensite }: 16.98 \%\end{array}$ \\
\hline
\end{tabular}

Berdasarkan hasil uji mikrostruktur mata pisau mesin irat bambu yang tersaji dalam Tabel 2. menunjukan heat treatment mata pisau mesin irat bambu dengan waktu penahanan 30 menit memiliki ukuran butir logam yang lebih halus dan merata dibandingkan heat treatment mata pisau mesin irat bambu dengan waktu penahanan 20 menit dan 10 menit. Ukuran butir logam yang terbentuk menjadi lebih halus mengakibatkan terjadinya peningkatan nilai kekerasan logam hal ini karena grain boundary yang semakin banyak dapat menghambat terjadinya dislokasi. Secara teoritik kekuatan sebanding dengan kekerasan, kekuatan akan naik dengan naiknya nilai kekerasan. Melalui heat treatment yang tepat, tegangan dalam dihilangkan, besar butir diperbesar atau diperkecil, ketangguhan ditingkatkan atau permukaan yang keras berada disekeliling inti yang ulet [4].

Mata Pisau Mesin irat bambu dengan holding time selama intercritical annealing 10 menit memiliki persentase fasa Ferit $90.37 \%$ dan Martensite $9.63 \%$, mata piasu dengan holding time selama intercritical annealing 20 menit memiliki persentase fasa Ferit $85.14 \%$ dan Martensite $14.86 \%$, mata pisau dengan waktu penahanan intercritical annealing 30 menit memiliki persentase fasa Ferit $83.02 \%$ dan Martensite $16.98 \%$, menunjukan bahwa terjadi peningkatan persentase fasa martensite dengan bertambahnya holding time selama intercritical annealing mata pisau mesin irat bambu. Peningkatan persentase pada fasa martensit menunjukan terbentuknya sifat mekanis berupa kekuatan tinggi dan keuletan yang baik [4]. Terbentuknya sifat mekanis ini terjadi dikarenakan fasa ferit yang memiliki sifat lunak/ulet dan fasa martensit yang memiliki sifat keras/ getas sehingga sifat mata pisau mesin irat bambu yang tebentuk berasal dari fasa ganda ferit-martensit atau merupakan gabungan antara sifat lunak/ ulet dengan keras/ getas.

Proses perlakuan mata pisau mesin irat bambu pada suhu di bawah suhu/ temperatur austenite dengan waktu penahanan tidak lebih dari 30 menit sehingga tidak terbentuk fasa perlit $(\mathrm{A}+\mathrm{P})$ karena dalam penelitian ini diharapkan terjadi pembentukan fasa ganda berupa ferit-martensite. Ketika fasa ferit sudah terbentuk maka fasa austenit akan berubah menjadi fasa martensite dengan melakukan proses austempering diikuti proses pendinginan/ mencelup mata pisau mesin irat bambu dalam larutan garam $350^{\circ} \mathrm{C}$ dan dilakukan penahanan selama 30 menit untuk sehingga membentuk fasa martensite.

\subsection{Hasil Uji Kekerasan}

Pengujian kekerasan mata pisau mesin irat bambu dilakukan dengan tujuan untuk mengetahui nilai kekuatan yang terbentuk setelah dilakukan proses heat treatment dengan variasi pada waktu penahanan masing - masing adalah 10 menit, 20 menit, dan 30 menit. Uji kekerasan dalam penelitian ini dilakukan pada 3 titik yang berbeda, hasil pengujian kekerasan ditunjukan dalam Tabel 3. 


\begin{tabular}{cccc}
\hline \multicolumn{4}{c}{ Tabel 3. Hasil Uji kekerasan } \\
\hline Titik Pengujian & \multicolumn{3}{c}{ Variasi } \\
\cline { 2 - 4 } & $\begin{array}{c}\text { Holding Time } \\
\text { 10 Menit }\end{array}$ & $\begin{array}{c}\text { Holding Time } \\
\text { 20 Menit }\end{array}$ & $\begin{array}{c}\text { Holding Time } \\
\text { 30 Menit }\end{array}$ \\
\hline 1 & 56.9 & 58.1 & 59.3 \\
2 & 57.3 & 57.9 & 58.3 \\
3 & 57.2 & 58.6 & 59.8 \\
Rata- Rata & 57.13 & 58.20 & 59.13 \\
\hline
\end{tabular}

Berdasarkan hasil uji kekerasan menunjukan bahwa nilai kekerasan HRC rata- rata tertinggi adalah pada mata pisau mesin irat bambu melalui proses heat treatment dengan holding time 30 menit dengan nilai HRC 59,13.

\subsection{Hasil Uji Tarik}

Uji tarik dalam penelitian ini dilakukan untuk mengetahui sifat mekanis mata pisau mesin irat bambu berupa ketahanan mata pisau mesin irat bambu terhadap kekuatan tarik sehingga mengalami deformasi plastis ketika menerima gaya, dengan megetahui nilai Modulus elastisitas (E) yang dapat diketahui dari pengukuran nilai tegangan tarik $(\sigma)$ maksimal dan nilai regangan $(\varepsilon)$. Hasil uji tarik pada mata pisau mesin irat bambu yang telah dilakukan proses heat treatment dengan variasi pada proses holding time masing masing adalah 10 menit, 20 menit, 30 menit ditunjukan dalam Tabel 4.

\begin{tabular}{lcccc}
\multicolumn{5}{c}{ Tabel 4. Hasil Uji Tarik } \\
& $\begin{array}{c}\text { Mata Pisau } \\
\text { No. }\end{array}$ & $\begin{array}{c}\sigma \mathrm{Max} \\
\left(\mathrm{N} / \mathrm{mm}^{2}\right)\end{array}$ & $\begin{array}{c}\varepsilon \\
(\%)\end{array}$ & $\begin{array}{c}\mathrm{E} \\
\left(\mathrm{N} / \mathrm{mm}^{2}\right)\end{array}$ \\
\hline Holding Time & 1 & 82.39 & 12.43 & 6.63 \\
10 menit & 2 & 81.97 & 12.20 & 6.72 \\
& 3 & 82.45 & 12.19 & 6.76 \\
Holding Time & 1 & 82.27 & 12.27 & 6.70 \\
20 menit & 2 & 82.96 & 12.39 & 6.70 \\
& 3 & 82.37 & 11.98 & 6.88 \\
Holding Time & 1 & 82.54 & 11.72 & 7.04 \\
30 menit & 2 & 82.62 & 12.03 & 6.87 \\
& 3 & 82.18 & 12.28 & 6.69 \\
& Rata- rata & 82.45 & 11.82 & 7.02 \\
& Rata-Rata & 82.54 & 12.56 & 6.56 \\
& & & & 6.76 \\
\hline
\end{tabular}

Sifat mekanis mata pisau mesin irat bambu berupa ketangguhan/ ketahanan bahan untuk mengalami deformasi elastis/ plastis ketika gaya diterapkan dapat kita lihat berdasarkan data hasil uji tarik pada Tabel 4 . Tabel tersebut menunjukan bahwa nilai rata- rata modulus elastisitas (E) tertinggi adalah pada mata pisau mesin irat bambu dengan holding time selama 20 menit yaitu $6,87 \mathrm{~N} / \mathrm{mm}^{2}$.

\section{Kesimpulan}

Berdasarkan hasil analisis dan pembahasan dapat diambil kesimpulan bahwa berdasarkan hasil uji struktur mikro mata pisau mesin irat bambu melalui heat treatment dengan holding time selama 30 menit memiliki ukuran butir logam yang lebih halus dan merata dibandingkan dengan pengujian pada pisau mesin irat bambu melalui heat treatment dengan holding time selama 10 menit dan 20 menit. Ukuran butir logam yang lebih halus mengakibatkan terjadinya peningkatan nilai kekerasan logam hal ini karena grain boundary yang semakin banyak dapat menghambat terjadinya dislokasi. Secara teoritik kekuatan sebanding dengan kekerasan, kekuatan akan naik dengan naiknya nilai kekerasan.

Fasa ganda ferit-martensit dengan komposisi tertinggi terbentuk pada mata pisau mesin irat bambu dengan holding time selama intercritical annealing selama 30 menit memiliki persentase fasa Ferit $83.02 \%$ dan Martensite $16.98 \%$. Peningkatan persentase pada fasa martensit menunjukan terbentuknya sifat mekanis berupa kekuatan tinggi dan keuletan yang baik [4]

Hasil uji kekerasan HRC rata-rata tertinggi ditunjukan pada mata pisau mesin irat bambu dengan dengan holding time 30 menit yang memiliki nilai rata-rata HRC 59,13. Peningkatan nilai kekerasan menunjukan adanya peningkatan sifat mekanis berupa[8].

Sifat mekanis berupa ketangguhan/ ketahanan mata pisau mesin irat bambu untuk mengalami deformasi elastis ketika mengalami gaya diketahui dengan nilai rata-rata modulus elastisitas (E) tertinggi adalah pada spesimen dengan waktu penahanan 20 menit yaitu $6,87 \mathrm{~N} / \mathrm{mm}^{2}$

\section{Daftar Rujukan}

[1] Darmawan, Agung Setio., 2007. Pengaruh Normalizing dan Tempering pada SCMnCr2 untuk memenuhi Standar JIS G 5111. Jurnal Media Mesin. Volume 8. Nomor 2 tahun 2007. Halaman 73-77.

[2] Davis, Joseph R., 2004. Tensile Testing, $2^{\text {nd }}$. Edition. ASM international.

[3] Fariadhie, J. 2012. Pengaruh Temper dengan Quenching Media Pendingin Oli Mesran SAE 40 terhadap Kekuatan Tarik dan Struktur Mikro Baja ST 60. Jurnal Politeknosains. Volume XI. Nomor 1 Tahun 2012. Halaman 126-137.

[4] Haryadi, G.D., 2006. Pengaruh Suhu Tempering Terhadap Kekerasan, Kekuatan Tarik dan Struktur Mikro Pada Baja K460. Jurnal Teknik Mesin. Volume 8. No.2. Halaman 1- 8

[5] Krar. Steve, Arthur Gill, Peter Smid., 2003. Machine Tool Technology Basics. Industrial Press Inc. United State Of America. New York

[6] Mulyadi dan Sunitra, Eka., 2010. Kajian Perubahan Kekerasan dan Difusi Karbon Sebagai Akibat Proses dari Proses Karburisasi dan Proses Quenching pada Material Gigi Perontok Power Thresher. Jurnal Teknik Mesin. Volume 7. Nomor 1. Halaman 33- 49.

[7] Nur, I. Junaidi dan Hanwar, O., 2005. Analisis Pengaruh Media Pendingin Dari Proses Perlakuan Panas Terhadap Kekuatan Sambungan Pegas Daun Dengan Las SMAW. Jurnal Teknik Mesin. Volume 2. Nomor 1. Halaman 18-23.

[8] Rahmawati, Rifki Isnaini dan Yunus., 2016. Analisis Frekuensi Gouging Terhadap Struktur Mikro, Struktur Makro, Tensile Strength, Dan Hardness Vickers Sambungan Pengelasan Baja SM490. JTM. Volume 04 Nomor 02 Tahun 2016, Halaman 6166.

[9] Schneider, George Jr., 2009. American Machinist. Penton Media, Inc. United State Of America.

[10] Wardoyo, J.T., 2005. Metode Peningkatan Tegangan Tarik dan Kekerasan PadaBaja Karbon Rendah Melalui Baja Fasa Ganda. Jurnal Teknik Mesin. Volume 10. Nomor 3. Halaman 237-248.

[11]Wulandari., 2011. Studi Ketahanan Korosi H2 Pada Baja Karbon Yang Mengalami Canai Hangat $600^{\circ} \mathrm{C}$. (Skripsi) Jurusan Teknik Metalurgi dan Material. Fakultas Teknik. Universitas Indonesia. Jakarta. Hal 8-1 